\title{
The Future of Biotechnology Litigation and Adjudication
}

\author{
Gregory N. MandeL*
}

This article pursues a difficult quarry: forecasting biotechnology issues expected to come before courts in the future. Predicting the future is a daunting enough challenge. Predicting the future of litigation and adjudication perhaps borders on foolish. My experience, both as a judicial clerk and in private practice, is that the only predictable thing about litigation is that it is unpredictable. Nevertheless, I believe I can provide some useful information concerning biotechnology issues that are likely to confront judges throughout North America and the world during the next several years, and some insight into understanding these issues and how to handle them.

First, I can explain what biotechnology is. Much litigation concerning scientific and technological issues is unnecessarily complicated by a failure to understand the science. Once the science is understood, even at a lay level, some legal issues resolve themselves surprisingly easily. Biotechnology is a perfect example. Though biotechnology presents several socially and politically highly charged issues, there actually is considerable scientific consensus on this technology's scientific benefits and risks. Setting aside the rhetoric simplifies many legal issues.

Second, I can provide a survey of past and present biotechnology litigation. Several biotechnology lawsuits already have been adjudicated or are being litigated, and existing litigation likely provides some of the most reliable insight into what to expect in the future.

Lastly, in my discussion of past and present biotechnology litigation, I will ignore better judgment, and mix in predictions

* (C) 2006 Gregory N. Mandel. Associate Professor of Law, Albany Law School. This article is based on a presentation at the The North American Symposium on the Judiciary and Environmental Law (Dec. 6-8, 2004), sponsored by the International Union for the Conservation of Nature and Natural Resources (IUCN), the United Nations Environmental Programme (UNEP), the New York State Judicial Institute, Pace University School of Law, and the Commission for Environmental Cooperation. Thais Triehy and Kelly Marks provided outstanding research assistance. 
about what trends and additional issues are in store for courts in biotechnology litigation and adjudication in the future. The article concludes with an analysis of, and recommendations for, the use of scientific evidence and expert testimony concerning biotechnology in the courtroom.

\section{BIOTECHNOLOGY}

The first, and most important, step in adjudicating biotechnology cases is to obtain a working understanding of what biotechnology is and is not. This part provides a primer on biotechnology and an update on the current status of genetically modified products. $^{1}$

\section{A. History and Science of Genetic Engineering}

The history of biotechnology begins in agriculture. Genetically modified crops, in a literal sense, have been around for centuries, probably since the advent of agriculture. In ancient times, farmers saved seeds from crops that produced the highest yield, proved the hardiest, or were the most disease resistant. Since at least the $1500 \mathrm{~s}$, farmers have bred crops in an effort to produce more durable, productive, or marketable varieties. Control over genetic modification of crops took a leap forward in the late 1800s with Gregor Mendel's discoveries regarding heredity and the inheritance of genetic traits, in particular, his finding that characteristics are inherited in a predictable manner. Since these discoveries, scientists and farmers have selectively bred closely related plants and animals in an effort to create hybrids with superior characteristics. Today, there are virtually no food products that have not been improved in some manner by selective breeding. ${ }^{2}$ Genetic modification through the breeding of plants and animals (which I will refer to as "conventional genetic modification"), however, is labor intensive (only one out of thousands of hybrids becomes a useful variety), can only be done among closely related

1. Part I of this article draws from Gregory N. Mandel, Gaps, Inexperience, Inconsistencies, and Overlaps: Crisis in the Regulation of Genetically Modified Plants and Animals, 45 WM. \& Mary L. REv. 2167 (2004).

2. Wild blueberries are one of the few remaining unmodified plant products. Examples of foods that have undergone particularly dramatic changes through conventional genetic modification include edible ears of corn (as opposed to corn with hard kernels that are inedible unless ground into flour), and the kiwi, which was developed from a hard little berry. 
species, takes a long time to produce desired results (usually a decade), and is often imprecise.

Scientists now are able to take genetic material responsible for a particular trait in one living species (whether plant, animal, insect, bacterium, or virus), and insert it into another species. $\mathrm{Be}$ cause the DNA building blocks for all living things are similar, desirable genes from any living organism can be inserted into any other living organism. This allows for modification of organisms at the cellular level, as opposed to conventional modification via breeding of the entire organism. If the genetic insertion is successful, the new genetic material in the host organism does what most genetic material does-it directs the production of specific proteins. These proteins determine the physical traits of living organisms. This method of modification uses recombinant DNA (rDNA) techniques, and is referred to as rDNA genetic modification, or more generally, "biotechnology." The modified rDNA organisms are commonly referred to as "genetically modified," "genetically engineered," "bioengineered," or "transgenic."3

rDNA genetic engineering offers many advantages over conventional breeding techniques. First, the organism being modified does not have to be sexually compatible with the organism from which the genetic material comes-one can take genes from bacteria and implant them into plants or animals, and vice versa. Second, new varieties can be produced much faster through rDNA methods than through conventional breeding techniques. Third, specific knowledge of the trait caused by the particular DNA being transferred can reduce variability in the offspring organisms. ${ }^{4}$

Biotechnology is thus the branch of biology that concerns technologically manipulating an organism's genetic sequence in order to give it certain desired traits. There are three main branches of biotechnology: medical, industrial, and agricultural. Medical biotechnology concerns trying to cure diseases through genetic manipulation. Some biomedical products, for instance, help in treating particular forms of cancer by targeting and blocking certain proteins that are being overproduced or by blocking

3. These terms are used synonymously in this article, each referring to the direct transfer or modification of genetic material using rDNA or other biotechnology techniques.

4. Gregory N. Mandel, Gaps, Inexperience, Inconsistencies, and Overlaps: Crisis in the Regulation of Genetically Modified Plants and Animals, 45 WM. \& Mary L. REv. 2167, 2174-76 (2004). Genetic engineering, however, also can be imprecise, as discussed infra at Part I.B.2. 
the flow of blood to a tumor. Industrial biotechnology concerns genetically modifying organisms to produce a protein or other product that is useful in industry, such as an oil, wax, or plastic. ${ }^{5}$ Agricultural biotechnology concerns genetically modifying plants and animals for agricultural or consumer benefit. These areas of biotechnology can overlap. For instance, a crop modified to produce a pharmaceutical compound could be considered to fall under any of the three categories. Because it was prepared for a conference on environmental law, this article focuses on agricultural biotechnology, with additional discussion of other biotechnology as well.

\section{B. Current Status of Genetically Modified Products}

Genetically modified food is already pervasive in the United States. The first genetically modified commercial food item, the Flavr Savr tomato (a slow-ripening tomato), was introduced in 1994. ${ }^{6}$ Since that time, genetically modified foods have become widespread, as over sixty types of transgenic plants have been commercialized. ${ }^{7}$ These plants include delayed-ripening crops, pest-resistant crops, herbicide-tolerant crops, virus-resistant crops, bacteria-resistant crops, fungus-resistant crops, and nematode-resistant crops, among others. ${ }^{8}$

Genetically modified crop production in the United States leads the worldwide industry, accounting for over half of the global transgenic crop. Combined, the United States, Argentina, Canada, and China account for 90 percent of the 200 million acres of genetically modified crop production worldwide. 9 Genetically engineered plants were grown on over 100 million acres of Ameri-

5. Id. at 2187.

6. See FDA, Ctr. for Food Safety \& Applied Nutrition, Office of Food Additive Safety, List of Completed Consultations on Bioengineered Foods (2005) [hereinafter List of Completed Consultations], http://www.cfsan.fda.gov/ lrd/biocon.html (listing sixty-six submissions completed through May 2005); see also Information Systems for Biotechnology, Tables for Field Test Releases and Petitions for Deregulation in the U.S. [hereinafter Tables for Field Test Releases], http://www.isb.vt.edu/cfdocs/isbtables2.cfm?tvar=4 (updated Oct. 11, 2005) (reporting that sixty-eight genetically modified plants have been deregulated).

7. See Tables for Field Test Releases, supra note 6.

8. See List of Completed Consultations, supra note 6.

9. The Pew Initiative on Food \& Biotechnology, Factsheet: Genetically Modified Crops in the United States (2004) [hereinafter Factsheet], available at http://pewagbiotech.org/resources/factsheets/display.php3?FactsheetID=2; see also Mike Toner, Biotech Plantings Up 20\%, U.S. Has Most Genetically Modified Crops, ATL. J. Const., Jan. 13, 2005, at 6A. 
can farmland in 2005, up from a mere 6 million acres in $1996 .^{10}$ In 2005,87 percent of soybeans, 52 percent of corn, and 79 percent of cotton grown in the United States were grown from genetically modified seeds; over half of the canola and papaya were genetically engineered as well.11 Estimates are that two-thirds of food on grocery store shelves contains ingredients from genetically modified crops, in everything from cereals and crackers, to juice and soda, to salad dressing and sauces. ${ }^{12}$

\section{Biotechnology Wonders}

Genetically modified crops are likely to become more varied and pervasive. The first generation of crops primarily was altered to provide agricultural benefits, such as pest resistance and herbicide tolerance, increased crop yield and quality, and lower production costs. ${ }^{13}$ Next-generation crops will be manipulated to create more nutritious foods and to produce plants that grow non-food products, such as pharmaceuticals, vaccines, vitamins, and industrial compounds. ${ }^{14}$ Numerous companies are working on producing pharmaceuticals that grow in plants. ${ }^{15}$ Once grown, the pharmaceuticals can be extracted from the plant, or in some instances, people may be able to eat the genetically engineered plant to obtain the benefit. ${ }^{16}$ In Canada, an anticoagulant agent represents the first commercialized pharmaceutical grown by a transgenic plant. ${ }^{17}$ Similarly, plants may be used to grow industrial compounds for uses such as detergent manufacturing, paper production, and mineral recovery. ${ }^{18}$ Other flora advances include

10. National Agricultural Statistics Service, USDA, Acreage 24-26 (2005), http://usda.mannlib.cornell.edu/reports/nassr/field/pcp-bba/acrg0605.pdf.

11. Id. at 24-25.

12. Mandel, supra note 4, at 2177. A list of crops that have been genetically modified includes: alfalfa, apple, barley, beet, broccoli, carrot, cassava, citrus, coffee, corn, cotton, cranberry, cucumber, eggplant, grape, grapefruit, lettuce, melon, oat, onion, papaya, pea, peanut, pear, pepper, peppermint, persimmon, pineapple, plum, potato, radicchio, rapeseed (canola), raspberry, rice, soybean, squash, stone fruit, strawberry, sugar beet, sugarcane, sunflower, sweet potato, tomato, walnut, watermelon, and wheat. (Not all of these crops have been commercialized, some are still under development.) Id. at 2177 n.20.

13. Mandel, supra note 4 , at 2181-82.

14. Id. at $2178,2186-90$.

15. Id.

16. Id.

17. Gregory A. Jaffe, Ctr. for Sci. Pub. Int., How to Approach a Regulatory Conundrum (May 19, 2002), http://www.cspinet.org/biotech/nabc_final.html.

18. Mandel, supra note 4 , at 2178 . 
trees being genetically engineered to grow faster, produce wood that is easier to process, or resist certain diseases. ${ }^{19}$

Research and development also is well underway for genetically modified fauna. Many laboratories are working on varieties of genetically modified fish, such as transgenic salmon, carp, catfish, trout, and shellfish, in an effort to increase rates of growth and reproduction, improve disease resistance, enhance cold tolerance, or provide other benefits. ${ }^{20}$ Proposals for the commercialization of these fish are currently under review. ${ }^{21}$

Transgenic cattle, sheep, pigs, chickens, goats, rabbits, and rodents are being developed. Goals here include increased growth rates, reduced fat levels, and improved disease tolerance, among others. Experimentation is under way to genetically engineer animals to produce human biologics and other products, including organs and tissues for human transplant. Animals may be modified to produce human proteins in their milk, which could then be extracted and purified for therapeutic use in humans. ${ }^{22}$

Even transgenic insects are being investigated. Insects domesticated for farming, such as the honeybee and silkworm, are being genetically engineered for disease resistance, and in the silkworm's case, to produce proteins other than silk. Insects also may be modified for improved use in programs to try to control other pest insects or invasive plant species. There likely will be attempts to replace or infiltrate native populations of insects with ones that have been genetically modified to be less of a pest or unable to transmit pathogens. Research is ongoing, for instance, to genetically modify mosquitoes to make them malaria resistant. ${ }^{23}$

In sum, genetically modified crops already are widely commercialized, and the commercialization of many next-generation biotechnology products is just around the corner. Further developments in rDNA technology and genomics are expected to lead to the accelerated development of even more new biotechnology

19. Id.

20. Other traits scientists are investigating include modification to allow marine fish to be raised in fresh water, improving tolerance to various environmental conditions, and enhancing nutritional qualities. Id. at 2178 n.25.

21. Mandel, supra note 4, at 2178 . On the novelty front, an aquarium fish genetically modified to glow in the dark became the first commercialized transgenic fish. $I d$. at 2178 n. 26 .

22. Mandel, supra note 4, at 2179. Other biologic products, such as blood and vaccine products, may be developed in this manner as well.

23. Id. at 2189. 
products, both in number and diversity. These biotechnology-derived products hold enormous promise for protecting human health and the environment, increasing agricultural production, improving medicine and nutrition, and providing economic benefit.

\section{Biotechnology Risks}

The great promise of genetically modified products does not come risk free. A complete survey of potential risks from transgenic products is beyond the scope of this article, but the categories of scientific risk are summarized in this section. ${ }^{24}$ The scientific risks generally can be divided into two categories: human health impacts and environmental or ecological concerns. Beyond these scientific risks are a variety of social and ethical concerns related to biotechnology that do not have direct human health or environmental consequences. Examples of such concerns include the potential industrialization or monopolization of agriculture, whether the insertion of certain genes violates religious rules or dietary restrictions, whether genetic engineering in the first instance violates ethical norms, and whether genetically modified products should be so labeled. These normative concerns are not analyzed in the following scientific discussion, but can play a significant role in biotechnology litigation, as discussed in Part II of this article.

At the outset, it is worth noting that there is no confirmed case of human disease or illness caused by genetically modified food. ${ }^{25}$ There are, however, still several human health concerns related to genetically modified food, primarily allergenicity and toxicity. ${ }^{26}$

Inserted genes express proteins, and certain proteins cause allergic reactions in some people, including serious harm such as anaphylactic shock or death. ${ }^{27}$ Because genetic modification causes the expression of new proteins, a new allergen may be introduced into a genetically engineered product. Scientists try to address allergenicity concerns by evaluating whether the newly

24. For a fuller discussion of the risks of genetically modified products, see Mandel, supra note 4, at 2190-2202.

25. Id. at 2190 .

26. Id. The risk of antibiotic resistance arising from the insertion of antibioticresistant genes is sometimes noted as an additional, indirect human health risk. There is now little scientific concern regarding an increase in antibiotic resistance from transgenic products. Id. at 2193.

27. Id. at 2190-91. 
expressed protein has a similar structure to known allergens; but this method is not foolproof, and allergenicity is considered one of the most difficult aspects in assessing the safety of transgenic products.

Toxicity is a concern due to the possible introduction of new toxins, or increases in the amounts of naturally occurring toxins, through genetic modification. Genetic modification of food also has the potential for unintended genetic consequences. This can occur both because gene insertion is an inexact process and because one cannot know what pleiotropic ${ }^{28}$ or synergistic effects may be caused by combining genes. ${ }^{29}$

The growth of pharmaceuticals or industrial compounds in plants raises enhanced concerns about the need for confinement and protection of the food supply. Such transgenic plants could get into the general food supply through multiple routes: The crops or seeds could be misrouted during processing, pollen from a transgenic crop could fertilize a nearby food crop, or the drug or compound could potentially leak from the plant roots into the soil. ${ }^{30}$

Genetically modified plants or animals may negatively impact the environment through several mechanisms. First, newly introduced genetic material may move into environments or organisms beyond those intended. This gene flow could occur in plants through the dispersal of genetically modified seeds; through the dispersal of the pollen of a genetically modified plant by wind, animals, or insects; or through the nonsexual transfer of genetic material from one organism to another, for instance, by virus or bacteria. ${ }^{31}$ Gene flow could occur in animals through breeding, such as an escaped transgenic fish breeding with a wild counterpart.

A second type of environmental impact from biotechnology is the spread of non-indigenous transgenic species into natural habi-

28. Mandel, supra note 4, at 2193-94. "Pleiotropic" effects are unintended genetic changes that result from the inserted genetic material having an effect beyond that intended on traits of the host organism. Id. at $2193 \mathrm{n.121}$.

29. Examples of the imprecision in genetic engineering to date include: genes for the color red placed into petunias not only changed the petunias' color, but also decreased their fertility and altered their growth; and salmon genetically engineered with a growth hormone gene not only grew too big too fast, but also turned green. In addition, there are many examples of conventional breeding projects that have resulted in hybrid offspring with traits that were unexpected based on knowledge of the parents' genes. Id. at 2194 n.122.

30. Id. at 2199.

31. Id. at 2194 . 
tats, which could cause the extinction of a wild species or other disruption of ecosystems. ${ }^{32}$ The introduction of transgenic plants tolerant to extreme temperatures, soil conditions, or climates, for example, could have impacts on other plant communities. Or, escaped transgenic fish could out-compete wild fish for resources such as food, space, and mates, particularly if the transgenic fish have been modified to improve fitness, adaptability, or survival traits.

A third environmental concern is hazard to non-target species. For instance, pest-protected plants may be toxic to insects and animals other than those targeted by the introduced pesticide. ${ }^{33}$

A common maxim stated in support of biotechnology is that it is no different than conventional genetic modification through breeding. As the above discussion makes clear, this statement contains kernels of truth, but also is misleading. Although both types of modification can lead to surprise or undesirable traits, biotechnology poses certain different risks. ${ }^{34}$ The differences between transgenic and conventional modification risk occur primarily because biotechnology allows a much broader array of genetic traits to be incorporated into a new organism than is possible through conventional breeding. Conventional breeding is limited by the available genetic variability in the target organism and its sexually compatible relatives. ${ }^{35}$ Genetic engineering removes these limits.

The degree of change in genetic information resulting from modification, whether conventional or biotechnological, can be measured along two dimensions: the number of genetic changes made and the taxonomic distance between the donor and host organisms. Changes of the former manner will vary in extent for both biotechnological and conventional modification. Changes of the latter manner, however, are much greater for genetic engineering than for conventional hybridization. ${ }^{36}$ Genetic engineering therefore can introduce specific traits or combinations, and create new exposures, that conventional engineering could not.

32. Mandel, supra note 4, at 2196-97. Genetically modified herbicide-tolerant canola plants, for example, are beginning to develop into a major weed problem in some parts of Canada. Id.

33. Id. at 2197.

34. Id. at $2252-53$.

35. Id.

36. Mandel, supra note 4, at 2253. 
In summary, genetic engineering holds the prospect of spectacular health, environmental, and economic benefits for society, but these benefits do not come risk free. Because genetically modified products pose certain risks and present uncertainty with respect to other concerns, it is not surprising that there has been, and is expected to be, litigation concerning biotechnology. The next part of this article reviews biotechnology litigation that has occurred or is ongoing, and offers insights into additional areas where litigation may be expected in the future. ${ }^{37}$

\section{BIOTECHNOLOGY LITIGATION AND ADJUDICATION-PAST, PRESENT, AND FUTURE}

Biotechnology litigation can be divided into several broad legal doctrinal categories: tort law, administrative law, nuisance, intellectual property, genetics issues, constitutional law, and antitrust law. Each of these categories is discussed below, followed by an analysis of the use of scientific evidence and expert testimony concerning biotechnology.

\section{A. Tort Law}

\section{Product Liability}

A producer is strictly liable for damages caused by its product if the product has a defect that renders it unreasonably dangerous and the producer knew or should have known of the danger. ${ }^{38} \mathrm{De}$ sign defect claims are one of the most likely forms of biotechnology product liability action. ${ }^{39}$ Should any of the human health or environmental concerns created by genetically modified products be realized or perceived to have occurred, product liability lawsuits are expected.

Some of the most significant biotechnology litigation to date involves product liability claims concerning the discovery of genet-

37. The discussion of biotechnology litigation in this article focuses on national law and litigation. Various biotechnology issues also raise international issues, particularly with respect to trade. These international concerns, however, are beyond the scope of this article.

38. See Restatement (Third) of ToRTs $\S 2$ (1998).

39. A design defect exists where there is another way to build the product that is safer than the manufactured version, and the alternative is cost-effective, no more or only slightly more expensive, and practical (i.e., it will not make the product difficult to use or cumbersome). Id. \& 2(b) (1998). 
ically engineered StarLink corn in human food. ${ }^{40}$ StarLink corn was not approved for human consumption because it carries transgenic genes that express a protein containing some attributes of known human allergens; it was approved only for use as animal feed and for non-food industrial purposes, such as ethanol production. ${ }^{41}$

In September 2000, StarLink corn was discovered in various brands of taco shells and later in many other human food products, eventually resulting in the recall of more than 300 products. ${ }^{42}$ Several of the United States' largest food producers were forced to stop production at certain plants due to concerns about StarLink contamination, and there was a sharp reduction in United States corn exports. ${ }^{43}$ Grain elevators and transporters were forced to institute expensive tests on corn shipments to assure that they were not contaminated. ${ }^{44}$

Many lawsuits were filed in connection with the StarLink corn contamination, a number of which were consolidated in In re StarLink Corn Products. ${ }^{45}$ In StarLink Corn, farmers alleging contamination of their corn crops brought a cause of action against the developer, producer, and distributor of StarLink, alleging design defect product liability. The farmers alleged that "as currently designed, StarLink cannot be safely used for its intended non-food purposes because it will inevitably commingle and cross-pollinate with the food supply." 46

Biotechnology product liability claims also may be based on manufacturing defects, as where a product differs from other similar products in a dangerous manner; ${ }^{47}$ or marketing defects, such as insufficiency in the warning or instructions that come with a

40. Mandel, supra note 4 , at 2203 .

41. Id.

42. $I d$. at 2204 .

43. Id. at 2204-05.

44. Id. at 2205 .

45. Kramer v. Aventis CropScience USA Holding, Inc. (In re StarLink Corn), 212 F. Supp. 2d 828 (N.D. Ill. 2002).

46. Id. at 837. Bayer CropScience's planting of genetically modified rapeseed that contained inadvertent additional genes in Britain could have presented similar issues. James Reynolds, Bayer Faces Prosecution After UK GE Crop Trials, ThE ScotsMAN, Oct. 14, 2003, available at http://www.gene.ch/genet/2003/Oct/msg00056.html. Bayer was conducting trials of transgenic rapeseed in England and Scotland over three years. Id. Some of the trial seeds were discovered to inadvertently contain antibiotic-resistant genes, often used to track genetic insertion. Bayer was not prosecuted. $I d$.

47. See Restatement (Third) of Torts $\S 2(a)$ (1998). 
product. ${ }^{48}$ Certain marketing defect claims were held to be effectively preempted by federal law in StarLink Corn,${ }^{49}$ but circumstances where a transgenic product is improperly used as a result of a failure to warn could form the basis for such a claim. ${ }^{50}$

Product liability claims also can sound in negligence, as opposed to strict liability. In StarLink Corn, the plaintiffs alleged that the defendants involved in producing and licensing StarLink Corn were negligent in their monitoring and enforcement of the steps required of farmers to keep StarLink Corn segregated. ${ }^{51}$ Negligence claims could also be grounded on failure to follow regulatory requirements or industry standards.

Certified organic farmers in Saskatchewan, Canada commenced an action against Monsanto Canada and Aventis CropScience (now Bayer CropScience) for the adventitious crosspollination of their organic canola by genetically modified canola manufactured and sold by Monsanto and Aventis. ${ }^{52}$ The plaintiffs alleged that the cross-pollination rendered the organic farmers' crop no longer organic. ${ }^{53}$ Certain of the farmers' claims were based on strict liability and negligence in causing the crosspollination. ${ }^{54}$

48. See id. § 2(c) (1998).

49. See In re StarLink Corn, 212 F. Supp. $2 d$ at 852 (holding that the strict product liability claim must be dismissed to the extent that the claim relied upon the failure of defendants to warn plaintiffs of potential spreading of genetically modified pollen, as such a claim is preempted by FIFRA). The court held that "plaintiffs may proceed on the theory that defendants (1) violated duties imposed by the limited registration; (2) made representations to StarLink growers that contradicted the EPA-approved label; and (3) failed to inform parties handling StarLink corn downstream of the EPA-approved warnings." Id. at 838.

50. See Pelman v. McDonald's Corp., 237 F. Supp. 2d 512, 532-33 (S.D.N.Y. 2003). In a non-biotechnology case, the plaintiffs sued McDonald's for inherently dangerous foods on the theory that McDonald's food processing had created more dangerous food than one would expect. Id. The court held that the plaintiffs had failed to establish a claim, but specifically stated in dicta that such a claim may lie for genetically modified food found to be dangerous because the danger may not be apparent. Id.

51. In re StarLink Corn, 212 F. Supp. 2d 828. The court dismissed the negligence claim to the extent that it relied on a failure to warn. Id. at 852; see supra note 49 and accompanying text.

52. Hoffman v. Monsanto Canada, Inc., [2003] 233 Sask. R. 112.

53. Id. at II 2 .

54. Statement of Claim, Hoffman v. Monsanto Canada, Inc., [2003] 233 Sask. R. 112 (Q.B. No. 67), available at http://www.saskorganic.com/oapf/pdf/stmt-of-claim.pdf. The negligence and strict liability causes of action were later dismissed by the court. Hoffman v. Monsanto Canada, Inc., [2005] 7 W.W.R. 665. The former claim was dismissed because the defendants did not owe the plaintiffs a duty of care; the latter was dismissed because there had not been an "escape" of a dangerous substance under the 
Product liability claims rate among the most likely biotechnology causes of action. They can be expected for almost any genetically modified product that is alleged to cause actual damages. This will include biotechnological medical malpractice. In one medical biotechnology case, for instance, the plaintiff alleged that the defendants' biotech drug impaired the plaintiff's immune system. ${ }^{55}$ I expect you will see product liability claims alleging allergenicity, toxicity, contamination, medical injury, and other damages by biotechnology products.

\section{Conversion}

Conversion requires "an intentional exercise of dominion or control over a chattel which so seriously interferes with the right of another to control it that the actor may justly be required to pay the other the full value of the chattel."56 Conversion may support an action based on the contamination of conventional crops with genetically modified crops.

StarLink Corn contained a conversion claim for the contamination of the plaintiff' non-StarLink crops, based on the contention that the contamination seriously interfered with the plaintiffs' ability to sell their crops. ${ }^{57}$ The court dismissed the conversion claim, holding that "[t]he crops were still viable for the purpose for which plaintiffs would normally use them, for sale on the open market." The court reasoned that the fact "that the market had become less hospitable does not change the product's essential character."58 Serious impairment of market value would likely support a conversion claim in some instances.

The rarely invoked doctrine of trespass to chattels may apply where conversion does not because the damage to the chattel is not serious enough. Trespass to chattels requires only that the chattel be impaired in condition, quality, or value, ${ }^{59}$ a requirement more easily met in many contamination cases.

Thus, future biotechnology conversion or trespass to chattels cases may be based on the contamination of organic crops with

strict liability theory pled by plaintiffs. Id. III 38-97. The court did not dismiss two regulatory causes of action. Id. III 159-94.

55. Cross v. Alpha Therapeutic Corp., No. 94-382, 2000 U.S. Dist. LEXIS 11804, at *17-18 (E.D. La.).

56. Restatement (SECOND) of ToRTs $§ 222 \mathrm{~A}(1)$ (1965).

57. In re StarLink Corn, 212 F. Supp. $2 d$ at 844.

58. Id.

59. See, e.g., CompuServe Inc. v. Cyber Promotions, Inc., 962 F. Supp. 1015, 1021 (S.D. Ohio 1997). 
genetically modified ones. ${ }^{60}$ To the extent contamination substantially reduces the value of the crop, or renders it unsuitable for its intended market, a claim of conversion or trespass to chattels may succeed.

\section{Tort Litigation Issues}

Class certification is expected to be routinely sought in a variety of biotechnology tort cases. Plaintiffs may seek certification of class (and such certification may be opposed) for standard strategic reasons including access to federal discovery rules, discovery efficiency, and expense.

Class action requirements ${ }^{61}$ make certification particularly appropriate in cases that involve market damages, such as the decline in value of an entire crop or refusal of foreign markets to buy certain crops due to genetically modified crop contamination. StarLink Corn involved a class action along these lines. ${ }^{62}$ Future class actions may be based on similar grounds, the contamination of organic crops, or the refusal of certain importers to purchase crops or crop products that may have genetically modified components. ${ }^{63}$

In a different vein, Sample $v$. Monsanto concerned plaintiffs' attempted class certification pursuant to antitrust and conspiracy claims. ${ }^{64}$ The Sample plaintiffs, corn and soybean farmers, alleged that the defendants had "conspired to fix, raise, maintain, or stabilize prices on genetically modified (GM) Roundup Ready soybean seeds and Yieldgard corn seeds in violation of the Sherman Act."65

60. Organic crops have been defined to exclude genetically modified crops. National Organic Program, 7 C.F.R. § 205.2 (2004).

61. Certification of a class in federal court requires:

(1) the class is so numerous that joinder of all members is impracticable,

(2) there are questions of law or fact common to the class, (3) the claims or defenses of the representative parties are typical of the claims or defenses of the class, and (4) the representative parties will fairly and adequately protect the interests of the class.

Fed. R. Crv. P. 23(a).

62. See In re StarLink Corn, 212 F. Supp. $2 \mathrm{~d}$ at 833.

63. The plaintiffs in Hoffman v. Monsanto attempted to obtain class certification for all organic farmers. [2003] 233 Sask. R. 112. See supra notes 51-54 and accompanying text. The court denied class certification, holding that the plaintiffs had failed to prove that all organic farmers had been financially hurt by genetically modified canola. Hoffman, 7 W.W.R. 665, III 239-46, 340.

64. Sample v. Monsanto Co., 218 F.R.D. 644 (E.D. Mo. 2003).

65. Id. at 646. Although the court held that plaintiffs met the requirements for numerosity, adequacy of representation, and commonality, they failed to show typi- 
Class actions and mass tort biotechnology litigation may raise issues concerning manufacturer identification. Where there are multiple producers of the product that is the subject of a suit, issues of collective or joint liability arise. With genetically modified products, however, these issues often will not be a concern because particular modifications may provide a signature allowing the product to be traced to a specific manufacturer.

\section{B. Administrative Law}

A wide variety of causes of action are expected concerning statutory and administrative regulations governing biotechnology. These actions can be divided into two categories: procedural actions against a governmental agency or service for improper promulgation of regulations, and substantive actions against entities for violating biotechnology regulations.

\section{Procedural Regulatory Actions}

Legal requirements for promulgating regulations vary among governmental entities. In the United States, for example, the Administrative Procedures Act (APA) provides certain procedures that federal agencies must follow when enacting regulations. ${ }^{66}$ Under the APA, federal agencies must publish all proposed new regulations in the Federal Register at least thirty days before they take effect, and must provide a means for interested parties to comment, offer amendments, or object to the proposed regulations. ${ }^{67}$

The creation of procedural requirements provides a useful means for plaintiffs seeking to challenge agency action because demonstration that an agency failed to engage in the appropriate procedures satisfies the elevated arbitrary and capricious standard courts use to review agency action. ${ }^{68}$ Thus, biotechnology actions challenging regulatory promulgation on procedural grounds can be expected. For example, although unsuccessful, the plaintiffs in Alliance for Bio-Integrity $v$. Shalala, challenged the Food

cality. Id. at 649. The court held that plaintiffs had failed to show that antitrust impact can be measured on a class-wide basis: "Plaintiffs cannot determine the butfor marketplace necessary to establish antitrust impact" using common proof. $I d$. at 651.

66. Administrative Procedure Act, 5 U.S.C. $\$ \S 551-559$ (2000).

67. 5 U.S.C. $\S 553$.

68. See Alliance for Bio-Integrity v. Shalala, 116 F. Supp. 2d 166, 174 (D.D.C. 2000); 5 U.S.C. $\$ 706(2000)$. 
and Drug Administration's (FDA's) Statement of Policy that genetically modified crops would be "'generally recognized as safe' [GRAS] ... and therefore not subject to standard requirements as food additives" as arbitrary and capricious. ${ }^{69}$

Other statutes create additional procedural requirements. The National Environmental Policy Act (NEPA), for instance, requires all federal agencies to consider the environmental impact of any proposed agency action prior to taking such action, and to prepare an Environmental Impact Statement (EIS) for any proposed action that is expected to significantly affect the environment. ${ }^{70}$

Several biotechnology actions have included NEPA claims, and more should be expected in the future. Plaintiffs were successful in their procedural NEPA challenge to agency action in Foundation on Economic Trends $v$. Heckler. ${ }^{71}$ The court held that the National Institute of Health's (NIH) approval of a deliberate release experiment involving genetically modified bacteria violated NEPA because the NIH failed to properly consider the possible environmental impact from dispersion of the bacteria. ${ }^{72}$ The plaintiffs in Alliance for Bio-Integrity also brought a NEPA claim based on the FDA's failure to prepare an EIS in connection with their Statement of Policy. ${ }^{73}$ However, the court, reasoning that inaction does not require preparation of an EIS, held that the FDA had not violated NEPA in deciding not to regulate biotechnology crops as food additives. ${ }^{74}$

\section{Substantive Regulatory Actions}

Substantive actions based upon the violation of properly promulgated regulations can be expected in all variety of forms. These actions may include failure to obtain proper authorization for growing or raising genetically modified products (for instance, certain transgenic crops require permits to grow); failure to com-

69. Alliance for Bio-Integrity, $116 \mathrm{~F}$. Supp. $2 \mathrm{~d}$ at 170 . The court held that the FDA's action was not arbitrary or capricious in light of the administrative record. In particular, the FDA did not violate the GRAS presumption because the only substances added to rDNA-engineered foods are nucleic acids and the proteins they produce, and nucleic acids and proteins are already in crops. Id. at 175-78. The case of Stauber v. Shalala, 895 F. Supp. 1178 (W.D. Wis. 1995) concerned a somewhat similar challenge to an FDA decision to approve a genetically modified growth hormone for use in cows to boost milk production. The FDA's decision was upheld here as well. Id.

70. 42 U.S.C. $\$ 4332(2)(C)(2000)$.

71. 756 F.2d 143 (D.C. Cir. 1985).

72. Id. at $152-60$.

73. Alliance for Bio-Integrity, 116 F. Supp. 2d at 170.

74. Id. at 175 . 
ply with permit or other regulatory requirements in the growth of biotechnology products (for instance, growth of certain transgenic crops requires various containment procedures); or impermissible impacts of genetically modified products (for instance, harming an endangered or threatened species in violation of the Endangered Species Act). ${ }^{75}$ The organic farmers in Hoffman $v$. Monsanto, for example, stated claims for violation of various environmental regulations based on the testing and release of transgenic canola; these regulatory causes of action were the only causes that survived dismissal. ${ }^{76}$

Actions for violation of statute or regulation may take surprising forms. Although not a biotechnology case, plaintiffs have successfully used the Clean Water Act ${ }^{77}$ to obtain an injunction against the stocking of fish farms with certain strains of conventionally bred salmon, on the basis that selective breeding of the farmed salmon has led to genetically different fish that could have a negative impact on wild salmon through cross-breeding between escaped farm salmon and wild salmon. ${ }^{78}$ This issue could arise for bioengineered fish or other transgenic animals as well.

\section{Nuisance}

\section{Private Nuisance}

A private nuisance is a nontrespassory intentional and unreasonable interference with another's use and enjoyment of his or her land that causes significant harm. ${ }^{79}$ Contamination of conventional crops by genetically modified crops may form the basis of a private nuisance claim.

75. 16 U.S.C. $\$ \S 1531-1544(2000)$.

76. See Statement of Claim, supra note 54; Hoffman v. Monsanto Canada, Inc., [2005] 7 W.W.R. 665, III 159-194.

77. 33 U.S.C. $\S \S 1251-1387$ (2000).

78. U.S. Public Interest Research Group v. Atlantic Salmon of Maine, LLC, 257 F. Supp. 2d 407 (D. Me. 2003). The cause of action under the Clean Water Act was failure to obtain an NPDES permit. The plaintiffs argued that "after several generations of selective breeding, farm-bred salmon differed genetically very significantly from wild salmon in fitness-related traits such as growth rate, age and size at sexual maturation, and number of eggs produced." Id. at 420. As a result, "farm escapees could have a negative genetic impact on wild salmon through cross-breeding," as the hybrid offspring "are likely to be less fit for survival than wild offspring." Id. at 421. The court held that "without regulation, the salmon farming operations present an imminent threat of irreparable harm to the wild Atlantic salmon populations in Maine," and granted an injunctive ban on the stocking of conventionally genetically modified strains. Id. at 434 .

79. Restatement (Second) of Torts $\$ \S 821 D, 822$ (1979). 
The plaintiffs in StarLink Corn stated a private nuisance cause of action based on the defendants' distribution of StarLink corn seeds with the knowledge that plants grown from the seeds would cross-pollinate nearby non-bioengineered corn crops. ${ }^{80}$ The court held that drifting transgenic pollen could constitute an invasion of land, and that contaminating crops interfered with the enjoyment of the land.81 Similarly, the plaintiffs in Hoffman $v$. Monsanto stated a nuisance cause of action based on the distribution of genetically modified canola with the knowledge that it would cross-pollinate organic canola. ${ }^{82}$

\section{Public Nuisance}

A public nuisance is an unreasonable interference with a right common to the general public. ${ }^{83}$ To prevail in public nuisance, private plaintiffs must demonstrate that they have been harmed differently from the general public. ${ }^{84}$

The plaintiffs in StarLink Corn stated a claim for public nuisance based on StarLink's general contamination of the corn food supply. ${ }^{85}$ The plaintiffs contended that corn farmers, as a group, were harmed differently from the general public due to the contamination. ${ }^{86}$ Like the private nuisance claim, the public nuisance claim also survived the motion to dismiss. The court held that the plaintiffs may be able to show that they have been harmed differently than the general public because they "depend

80. In re StarLink Corn, 212 F. Supp. $2 \mathrm{~d}$ at 845.

81. Id. The more difficult issue for the court concerned whether the defendants could be liable for contamination caused by the product after its sale. The court held that all parties who contribute substantially to a nuisance are liable, even after sale of the product. $I d$. at 847 .

82. Hoffman v. Monsanto Canada, Inc., [2003] 233 Sask. R. 112. The plaintiffs also stated a cause of action for trespass. Both the nuisance and trespass causes of action were dismissed for failure to state a claim because the defendants only invented and manufactured the genetically modified product, but were not responsible for its release. Hoffman v. Monsanto Canada, Inc., [2005] 7 W.W.R. 665, IIT 98-133. A trespass action would be unlikely to succeed under United States law as well, due to the nominal nature of the trespass of pollen.

83. Restatement (Second) of Torts $\$ 821 \mathrm{~B}$ (1979).

84. Id.

85. In re StarLink Corn, 212 F. Supp. $2 d$ at $844-45$, 848. The public nuisance claim was thus premised on contamination of the general corn food supply, while the private nuisance claim was premised on cross-pollination of the farmers' fields. The court stated that a private nuisance claim could not be supported by contamination of the general food supply as "[c]ommingling could not constitute a private nuisance because it does not involve an invasion of any private interests in land." Id. at 845 n.12.

86. Id. at 848 . 
on the integrity of the corn supply for their livelihood."87 Thus, contamination of organic crops may give rise to both private and public nuisance actions.

\section{Intellectual Property}

\section{Patent Infringement}

Most genetically modified products are covered by patent protection, so patent validity and infringement issues represent a large area of biotechnology litigation. ${ }^{88}$ Traditional patent validity issues and litigation generally do not raise new legal issues as a result of involving biotechnology inventions. ${ }^{89}$ A couple of new wrinkles do arise, and are discussed below.

Crops grown from genetically modified seed will produce genetically modified seed-the modification is passed from the crop to its progeny seed. This presents a problem for biotechnology companies seeking to maximize their profits: Having purchased genetically modified seeds, the grower can raise the crops, harvest the seeds, and never have to purchase the product again. Producers of genetically modified seeds combat this problem by usually only selling their patented seeds pursuant to licensing agreements that contractually prohibit growers from harvesting seeds produced by the transgenic crops after they are grown.90

87. Id.

88. See, e.g., Plant Genetic Sys. v. Dekalb Genetic Corp., 315 F.3d 1335 (Fed. Cir. 2003) (holding patent on genetically modified herbicide-resistant plants not infringed because the cell patent claims were invalid for lack of enablement); Monsanto Co. v. Bayer Bioscience N.V., 363 F.3d 1235 (Fed. Cir. 2004) (reversing district court's holding that four patents for transgenic pest-protected corn were invalid because of inequitable conduct during prosecution of the parent application, and remanding for further proceedings); Amgen, Inc. v. Hoechst Marion Roussel, Inc., 314 F.3d 1313 (Fed. Cir. 2003) (holding that challenged biotechnology patents for the production of erythroprotein were effective); Chiron Corp. v. Genentech, Inc., 363 F.3d 1247 (Fed. Cir. 2004) (holding that patents on particular monoclonal antibodies that bind to a human breast cancer antigen were invalid because Chiron did not adequately disclose or support the subject matter of its patents); Univ. of Rochester v. G.D. Searle \& Co., 358 F.3d 916 (Fed. Cir. 2004) (holding patent on methods of selectively inhibiting certain enzyme activity invalid for failure to identify a required compound).

89. Patenting of biotechnology subject matter does raise certain nuanced patent validity issues, but these issues are beyond the scope of this article. See, e.g., In re Deuel, 51 F.3d 1552 (Fed. Cir. 1995) (creating an arguably different non-obvious standard for patent validity for biotechnology inventions); Regents of the Univ. of Cal. v. Eli Lilly, 119 F.3d 1559 (Fed. Cir. 1997) (creating an arguably different written description requirement for patent validity of biotechnology inventions).

90. See infra note 91 . 
A number of lawsuits, in both the United States and Canada, have been brought by genetically modified seed producers against growers for harvesting genetically modified seeds or growing genetically modified plants in violation of the licensing agreements. These actions are based on patent infringement claims, as growers who violate their license agreement do not have a license to plant the patented seeds that they are using, and thus are using a patented product without permission. Genetically modified seed producers have routinely won these patent infringement cases. ${ }^{91}$

A second patent law twist concerns "biopiracy." Biopiracy is the "unauthorized and uncompensated expropriation of traditional knowledge and resources"92_for instance, expropriating native knowledge that a certain plant has medicinal qualities. Several developing countries, including India, the Philippines, and Brazil, have implemented intellectual property or similar legal protection for genetic resources and traditional knowledge. ${ }^{93}$ In general, these laws require entities seeking to patent inventions based on genetic resources or traditional knowledge to compensate claimants or the country itself. ${ }^{94}$ The Convention on

91. See Monsanto Co. v. McFarling, 363 F.3d 1336 (Fed. Cir. 2004) (holding farm operator liable for patent infringement for violating technology license, and denying farm operator's claim that the technology license was invalid for patent misuse); Monsanto Co. v. Ralph, 382 F.3d 1374 (Fed. Cir. 2004) (granting Monsanto a reasonable royalty for the patent infringement where defendant saved seeds containing patented Roundup-Ready biotechnology for use the next year); Monsanto Co. v. Swann, 308 F. Supp. 2d 937 (2003) (finding use of harvested glyphosate herbicide-resistant seeds in violation of license to be an infringement of Monsanto's patent rights); Monsanto Co. v. Hartkamp, No. 00-164-P, 2001 U.S. Dist. LEXIS 25253 (E.D. Okla. Apr. 19, 2001) (finding infringement on Monsanto's patent rights by planting Roundup-Ready soybeans in violation of license); Monsanto Co. v. Roman, No. 1:03-CV-068-C, 2004 U.S. Dist. LEXIS 10724 (N.D. Tex. May 17, 2004) (granting Monsanto's motions for partial summary judgment and injunctive relief based on defendant's act of saving Monsanto's patented seeds and planting the next year); Monsanto Canada Inc. v. Schmeiser, 2004 S.C.C.D. LEXIS 48 (finding that Schmeiser knew or should have known that he saved and planted seed containing the patented gene and cell and sold the resulting crops).

92. Michael Woods, Food for Thought: The Biopiracy of Jasmine and Basmati Rice, 13 Alb. L.J. ScI. \& TECH. 123, 134 (2002) (quoting Valentina Tejera, Note, Tripping Over Property Rights, 33 New ENG. L. REv. 967, 971-72 (1999)).

93. Thomas Cottier \& Marion Panizzon, Legal Perspectives on Traditional Knowledge: The Case for Intellectual Property Protection, 7 J. INT'L Econ. L. 371, 380-81 (2004).

94. See, e.g., id. See also Laurence R. Helfer, Regime Shifting: The TRIPs Agreement and New Dynamics of International Intellectual Property Lawmaking, 29 YALE J. INT'L L. 1, 6, 31-33 (2004); Woods, supra note 92; Lakshmi Sarma, Biopiracy: Twentieth Century Imperialism in the Form of International Agreements, 13 TEMP. INT'L \& Comp. L.J. 107 (1999); Timothy P. Daniels, Keep the License Agreements Coming: The Effects of J.E.M. Ag Supply, Incorporated v. Pioneer Hi-Bred International, Incorpo- 
Biodiversity, which the United States has not ratified or approved, provides some international protection for genetic resources. ${ }^{95}$ For instance, commercially successful use of a developing country's genetic resources can require compensation. ${ }^{96}$ Most developed countries, however, do not provide enforceable protection of indigenous knowledge or genetic natural resources.

\section{Patent-Eligible Subject Matter}

An ongoing debate concerns whether genetically modified organisms should be eligible for patent protection at all. This debate pits those who argue that bioengineered organisms are inventions worthy of patent protection against those who contend that the patenting of living organisms violates ethical or moral standards.

This question was settled legally in the United States a quarter century ago, without much public debate, when the Supreme Court held in Diamond v. Chakrabarty that genetically modified bacteria were patent eligible. ${ }^{97}$ Since that time, numerous patents have been granted on various genetically modified life forms. ${ }^{98}$ Isolated and purified genes also are patent eligible in the United States. This includes isolated and purified human genes, although claims "encompassing a human organism" may not be granted based on an appropriations restriction. ${ }^{99}$

Other countries have not answered this question quite as simply. The Canadian Supreme Court, for example, recently held that the "onco-mouse"-a mouse genetically modified to be particularly susceptible to breast cancer and therefore useful in re-

rated on Universities' Use of Intellectual Property Laws to Protect Their Plant Genetic Research, 2003 BYU EDUc. \& L.J. 771 (2003).

95. See Helfer, supra note 94, at 28-32; Convention on Biological Diversity, Parties Information, http://www.biodiv.org/world/parties.asp (last visited Nov. 8, 2005).

96. See Helfer, supra note 94 , at 31.

97. See Diamond v. Chakrabarty, 447 U.S. 303 (1980).

98. See, e.g., U.S. Patent No. 4,736,866 (filed June 22, 1984) (issued Apr. 12. 1988) (transgenic non-human mammals, based on the Harvard Onco-Mouse, a mouse genetically modified to be highly susceptible to cancer); U.S. Patent No. 5,175,383 (filed Feb. 17, 1989) (issued Dec. 29, 1992) (genetically modified mouse); U.S. Patent No. $5,175,385$ (filed Sept. 3, 1987) (issued Dec. 29, 1992) (genetically modified virus-resistant mouse).

99. Science, State, Justice, Commerce, and Related Agencies Appropriations Act of 2006, § 623, Pub. L. No. 109-108, 119 Stat. 2290, 2342. 
search-was not patent eligible. ${ }^{100}$ The Court held that genetically modified higher life forms (such as animals) are not patent-eligible inventions. ${ }^{101}$ Genetically modified microorganisms are, however, patent eligible in Canada. ${ }^{102}$

A closely related debate arises over the propriety of cloning. To date, however, few countries have acted to ban cloning.

\section{E. Genetics Issues}

\section{Genetic Property Rights}

Some unusual biotechnology cases concern whether or to what extent a person owns property rights in his or her genes or genetic characteristics. These cases arise when a researcher has used organs, tissue, or other genetic or DNA samples from a person to achieve some medical breakthrough. The cases concern whether the individual whose genetic material was used possesses any property right or other interest in the invention.

Two primary American cases illustrate this issue. In Moore $v$. Regents of the University of California, Moore's spleen was removed for medically indicated reasons. ${ }^{103}$ Extracted cells from the spleen were used in medical biotechnology experiments, possibly without his knowledge or consent, and a resulting cell-line was patented. ${ }^{104}$ Moore claimed an interest in the patent and cell-line, and brought suit against the patent owner. ${ }^{105}$ The California Supreme Court held that Moore did not have a property interest in his cell-line sufficient to support a claim for conversion. ${ }^{106}$ In

100. Harvard Coll. v. Canada (Comm'r of Patents), [2002] 4 S.C.R. 45, 2002 SCC 76, available at http://www.lexum.umontreal.ca/csc-scc/en/pub/2002/vol4/html/ 2002scr4_0045.html.

101. $I \bar{d}$. The Court held that genetically modified higher life forms are not a "manufacture" or "composition of matter" within the meaning of "invention" in the Canadian Patent Act. Id. at III 160-61. The debate over the patent eligibility of genetically modified organisms has followed a particularly long and twisting path in Europe, with most countries now allowing such patenting.

102. Id. at II 10 .

103. Moore v. Regents of the Univ. of Cal., 793 P.2d 479, 481 (Cal. 1990). This case received significant publicity, in part for the $\$ 3$ billion value attached to Moore's cellline in the complaint. This case, however, was decided on appeal from a granted demurrer; as such, the facts were assumed to be those stated in the complaint. In reality, the cell-line was never commercialized.

104. Id.

105. Id. at 487.

106. Id. The court reasoned, "First, a fair balancing of the relevant policy considerations counsels against extending the tort. Second, problems in this area are better suited to legislative resolution. Third, the tort of conversion is not necessary to protect patients' rights." Id. at 493. The court did uphold Moore's separate cause of action for 
reaching this decision, the court explicitly identified the strong policy reasons of limiting civil liability for innocent parties engaged in socially useful activities by noting that "the extension of conversion law into this area will hinder research by restricting access to the necessary raw materials."107

In Greenberg v. Miami Children's Hospital Research Institute, Inc. the plaintiffs included individuals with Canavan's disease and their family members. ${ }^{108}$ The plaintiffs approached a doctor to persuade him to research a cure for Canavan's disease and provided genetic samples and financial support to further the research. ${ }^{109}$ The doctor successfully isolated and patented the gene responsible for Canavan's disease. ${ }^{110}$ Miami Children's Hospital, assignee of the patent, decided to limit Canavan disease testing through restrictive licensing under the patent. ${ }^{111}$ The plaintiffs brought suit, seeking a property right or other interest in the patent and discovery. ${ }^{112}$ As in Moore, the court held that the plaintiffs had no property interest in their donated body tissue or genetic information, which had been voluntarily provided. ${ }^{113}$ The Greenberg court also noted concerns that creating an interest for donors could potentially cripple medical research. ${ }^{114}$

\section{Genetic Identification}

Advances in genetic identification and recognition raise a diverse array of new legal issues. These issues can only be briefly surveyed here. A primary concern is the potential for genetic discrimination, for instance by health insurance companies against individuals with genes that place them at higher risk for certain diseases. ${ }^{115}$ Genetic discrimination is also a concern in other con-

breach of informed consent. Id. at 483,487 . The case settled before this issue was further litigated.

107. Id. at 494.

108. Greenberg v. Miami Children's Hosp. Research Inst., Inc., 264 F. Supp. 2d 1064, 1066 (S.D. Fla. 2003).

109. Id.

110. Id. at 1067.

111. Id.

112. Id. at 1068.

113. Id. at 1074-75. Plaintiffs' claim for unjust enrichment did survive the motion to dismiss. Id. at 1072. This case settled as well, with Miami Children's Hospital allowing the gene to be used for further research.

114. Id. at 1076.

115. See Deborah Hellman, What Makes Genetic Discrimination Exceptional?, 29 AM. J.L. \& MED. 77 (2002); Jennifer S. Geetter, Coding for Change: The Power of the Human Genome to Transform the American Health Insurance System, 28 AM. J.L. \& MED. 1 (2004). 
texts, such as employment, life and disability insurance, or child custody and adoption decisions. ${ }^{116}$ Most states have enacted legislation prohibiting genetic discrimination in providing health insurance. ${ }^{117}$

Many states have passed laws requiring the submission of a DNA sample by individuals accused, indicted, or convicted of certain crimes. ${ }^{118}$ These laws have been challenged, unsuccessfully, as unreasonable searches and seizures under the Fourth Amendment, ${ }^{119}$ violations of the Equal Protection Clause, ${ }^{120}$ violations of the prohibition against self-incrimination under the Fifth Amendment, ${ }^{121}$ deprivation of property rights without due process or just

116. Hellman, supra note 115 , at 77.

117. See Nat'l Conference of State Legislatures, Genetic and Health Insurance: State Anti-Discrimination Laws, http:www.ncsl.org/programs/health/genetics/ ndishlth.htm (last visited Nov. 24, 2005) (showing that forty-three of the fifty states have enacted laws prohibiting genetic discrimination in health insurance). See also William F. Mulholand \& Ami Jaeger, Genetic Privacy and Discrimination: A Survey of State Legislation, 39 JuRIMETRICS J. 317 (1999) (describing state anti-discrimination legislation). A federal anti-genetic discrimination bill passed the Senate in 2003, but was not enacted. See Genetic Information Nondiscrimination Act of 2003, S. 1053, 108th Cong. (2003).

118. Mark A. Rothstein \& Sandra Carnahan, Legal and Policy Issues in Expanding the Scope of Law Enforcement DNA Data Banks, 67 Brook. L. Rev. 127 (2001).

119. See, e.g., Gaines v. Nevada, 998 P.2d 166, 172 (Nev. 2000). In Gaines, an individual convicted of non-violent crimes challenged a requirement to submit a DNA specimen as an unreasonable search and seizure under the Fourth Amendment. The court applied a balancing test and found that the state's interest in solving crimes outweighed the convict's expectations of privacy and the intrusive nature of the blood draw; thus, the Fourth Amendment was not violated. Id. at 172. See also Nicholas v. Goord, 2004 Dist. LEXIS 11708 (S.D.N.Y.) (analyzing a New York statute authorizing genetic testing of convicts under a Fourth Amendment balancing test and finding that the statute's primary purpose was to solve crimes, and therefore outweighed the convict's privacy interests); United States v. Kincade, 379 F.3d 813 (9th Cir. 2004) (looking at the totality of the circumstances to determine that a California law requiring prisoners to submit to DNA testing did not violate the Fourth Amendment).

120. See, e.g., Roe v. Marcotte, 193 F.3d 72 (2d Cir. 1999). In Marcotte, the plaintiffs unsuccessfully argued

that the statute violates the Equal Protection Clause because it (1) impermissibly distinguishes between individuals convicted of crimes characterized as sexual offenses and those convicted of other violent offenses, (2) targets incarcerated sex offenders but not prior sex offenders who currently reside in the community, and (3) targets convicted sex offenders whether or not their current incarceration is for a sex offense.

Id. at 82 .

121. See, e.g., Boiling v. Romer, 101 F.3d 1336, 1340-41 (10th Cir. 1996) (holding that the DNA databank statute did not violate plaintiff's Fifth Amendment right against self-incrimination because DNA evidence is not testimonial in nature). 
compensation under the Takings Clause, ${ }^{122}$ ex post facto laws, ${ }^{123}$ cruel and unusual punishment under the Eighth Amendment, ${ }^{124}$ and even on separation of powers grounds. ${ }^{125}$ Intertwined in both the discrimination and DNA sampling debates is the heavily contested issue of whether and what genetic privacy rights exist. ${ }^{126}$

More imaginative genetics claims have been litigated as well. A woman who developed colon cancer sued her father's physician for negligently failing to warn her of the genetic nature of her father's colorectal cancer. ${ }^{127}$ The daughter claimed that if she had been warned, she would have undergone testing for early detection of her disease, and would not have required as extensive surgical treatment. ${ }^{128}$ The court held the doctor liable for failure to warn "those known to be at risk of avoidable harm from a genetically transmissible condition."129 The court reasoned that the genetic threat was foreseeable and the group at risk was easily identifiable. ${ }^{130}$ Similarly, a physician was held to have breached his duty of care for failing to perform genetic testing of the parent of a patient with Fragile X Syndrome, a disorder with a high probability of genetic transmission, in order to diagnose the disorder. ${ }^{131}$ These examples indicate that genetics litigation is likely to continue in the future.

122. See, e.g., id. (holding that the Colorado statute compelling inmates to submit to DNA testing does not implicate a liberty interest protected by due process or a property interest).

123. See, e.g., Rise v. Oregon, 59 F.3d 1556, 1562 (9th Cir. 1995) ("Because [the statute's] obvious purpose is to create a DNA data bank to assist in the identification, arrest, and prosecution of criminals, not to punish convicted murderers and sexual offenders, it does not violate the prohibition against ex post facto punishment.").

124. See, e.g., Kruger v. Erickson, 875 F. Supp. 583, 588 (D. Minn. 1994) (holding that taking blood did not amount to "the unnecessary and wanton infliction of pain" under the Eighth Amendment because of the legitimate interest of constructing a DNA database of criminal sex offenders).

125. See, e.g., Dial v. Vaugh, 733 A.2d 1, 4-6 (Pa. Commw. Ct. 1999) (holding that the DNA databank statute of Pennsylvania did not violate separation of powers requirements because it did not affect appellant's eligibility for parole or alter his sentence length).

126. See Sonia M. Suter, Disentangling Privacy from Property: Toward a Deeper Understanding of Genetic Privacy, 72 GEo. WASH. L. REv. 737, 762, 776 (2004) (arguing that "genetic privacy ... protects personhood interests in shielding us against stigmatization, discrimination, and being misunderstood.").

127. Safer v. Estate of Pack, 677 A.2d 1188 (N.J. Super. Ct. App. Div. 1996).

128. Id. at 1190 .

129. Id. at 1192 .

130. Id.

131. Molloy v. Meier, 679 N.W.2d 711, 719-20 (Minn. 2004). 


\section{F. Constitutional Law}

Certain biotechnology cases implicate constitutional concerns. International Dairy Foods Association v. Amestoy involved an industry challenge to a Vermont statute that required the placement of a blue dot on products that contained milk from cows treated with a genetically modified growth hormone (known as rBGH) designed to boost milk production. ${ }^{132}$ Certain dairy manufacturers and food retailers challenged the labeling requirement as a violation of their First Amendment right not to speak. ${ }^{133}$ The Second Circuit concurred, holding that because neither consumers nor scientists could distinguish between milk from a cow treated with $\mathrm{rBGH}$ and milk from an untreated cow, the manufacturers and retailers could not be required to speak against their will. ${ }^{134}$

Conversely, in Ben \& Jerry's Homemade, Inc. v. Lumpkin, the plaintiffs sued Illinois on First Amendment speech grounds for preventing the plaintiffs from labeling their goods as not containing rBGH. ${ }^{135}$ The case settled when Illinois allowed the voluntary labeling of non-rBGH food products, and the parties reached a compromise on the language to be used on the labels. ${ }^{136}$

132. Int'l Dairy Foods Ass'n v. Amestoy, 92 F.3d 67 (2d Cir. 1996). In accordance with FDA requirements, the Vermont regulations required a posting of a disclaimer that "the [FDA] has determined that there is no significant difference between milk from treated and untreated cows." Id. at 70 (quoting Adopted Rules (rBST Notification and Labeling Regulations Relating to Milk and Milk Products) of Vermont Dep't of Agriculture, Food and Markets $\S 3.1 \mathrm{~b}$ ).

133. See Amestoy, 92 F.3d 67.

134. Id. The court held that consumer curiosity alone (the only interest that Vermont argued) was not a strong enough state interest to compel even an accurate factual statement. $I d$. at 74 . In a similar action, Monsanto sued a large Maine dairy to challenge a voluntary program Maine used to certify in-state producers who did not use rBGH on the grounds that such labeling constituted misleading advertising and imposed unlawful restrictions on market access. Complaint for an Injunction, Monsanto Co. v. Oakhurst Dairy Inc., No. 03-11273RCL (D. Mass. filed July 3, 2003). This suit was settled when Oakhurst Dairy agreed to add a disclaimer to its label which read: "FDA States: No significant difference in milk from cows treated with artificial growth hormones." See Douglas A. Kysar, Preferences for Processes: The Process / Product Distinction and the Regulation of Consumer Choice, 118 HARv. L. REv. 525, 574 n.210 (2005) (citing Edward D. Murphy, Oakhurst to Alter Its Label, PorTland Press Herald, Dec. 25, 2003, at A1).

135. Ben \& Jerry's Homemade, Inc. v. Lumpkin, No. 96 C 2748, 1996 U.S. Dist. LEXIS 12469, at *2 (N.D. Ill. Aug. 27, 1996).

136. Ben \& Jerry's, State in Accord on Growth Hormone Statement, CHI. TRIB., Aug. 14, 1997, at 4. Under the agreement, Ben \& Jerry's products may say:

We oppose Recombinant Bovine Growth Hormone. The family farmers who supply our milk and cream pledge not to treat their cows with $\mathrm{rBGH}$. The FDA (Food and Drug Administration) has said no significant differ- 
In Alliance for Bio-Integrity $v$. Shalala, the plaintiffs challenged the FDA's decision not to require labeling of genetically modified products as a violation of the Religious Freedom Restoration Act. ${ }^{137}$ The plaintiffs argued that without labels, individuals with religious dietary restrictions would not be able to follow their restrictions because they would not know whether a gene from an unacceptable animal (e.g., a pig for certain religions) may have been inserted into an otherwise acceptable food. ${ }^{138}$ The court held that the lack of a labeling requirement did not substantially burden plaintiffs' practice of their religions because the FDA action did not require anyone to abandon their religious beliefs or practices. $^{139}$

\section{G. Antitrust Law}

Although there has not yet been much biotechnology litigation in the area of antitrust law, courts will likely see many antitrust actions related to biotechnology in the future. Most genetically modified products are subject to patent or other intellectual property protection that confers a legal monopoly on the owner. As a result, allegations of illegal monopoly and of exercise of illegal monopoly power are particularly likely.

At least a few biotechnology antitrust actions have been filed to date. Sample v. Monsanto concerned plaintiff corn and soybean farmers who alleged that the defendants had "conspired to fix, raise, maintain, or stabilize prices on genetically modified (GM) Roundup Ready soybean seeds and Yieldgard corn seeds in violation of the Sherman Act."140 In Monsanto v. McFarling, the defendants raised an affirmative defense that the technology license McFarling had signed (and violated) was invalid because Monsanto had committed patent misuse, and consequentially antitrust violations, by tying rights to use offspring of transgenic seeds to the patented parent seeds. ${ }^{141}$ Both actions were unsuccessful.

The intersection of intellectual property rights and antitrust violation represents a complex area of law beyond the scope of this

\footnotetext{
ence has been shown and no test can now distinguish between milk from rBGH-treated and untreated cows.

Id.

137. Alliance for Bio-Integrity v. Shalala, 116 F. Supp. 2d 166, 180 (D.D.C. 2000).

138. Id. at 181.

139. Id.

140. Sample v. Monsanto Co., 218 F.R.D. 644, 646 (E.D. Mo. 2003).

141. Monsanto Co. v. McFarling, 363 F.3d 1336 (Fed. Cir. 2004).
} 
article. In general, however, the antitrust issues raised concerning biotechnology should be unaffected by the fact that monopoly power is being challenged with regard to a biotechnology product.

\section{EXPERT TESTIMONY ON BIOTECHNOLOGY}

Scientific expert testimony will play a significant role in much biotechnology litigation and adjudication. Because certain biotechnology issues concern matters at the forefront of scientific knowledge and present significant scientific uncertainty, use of expert evidence in this area will be particularly challenging for judges. It has been, and likely often will be, the case that the parties produce well-qualified scientific experts and proffer scientific evidence that is diametrically opposed. In this situation, it is important for courts to sift through the evidence to try to get as good a handle as possible on what the actual level of scientific understanding is.

There are several factors to consider when contemplating the use of expert testimony in biotechnology litigation and adjudication. The first is to explicitly recognize what is already knownneither side's expert may be promoting the current best state of scientific knowledge. Rather, each side is presenting evidence that best supports its case-which may be partially correct, and partially a stretch. Best current scientific understanding is often a third body of knowledge that neither side introduces into evidence because it does not make their case as cleanly as desired. In this regard, one study found that four out of five judges do not believe that party expert witnesses can be counted on to be impartial. ${ }^{142}$

Thus, judges should often exercise their discretion in biotechnology cases to acquire and admit independent, non-party expert evidence. This will usually give the decision-maker the least-biased view of the state of scientific knowledge, and allow them to focus on the true legal dispute and scientific issues in contention in order to achieve the most just result possible.

The primary means to achieve this goal is the use of courtappointed experts. Court-appointed experts offer many advantages. They can highlight the (often considerable) areas of scientific agreement and consensus. The litigation can then concentrate on the narrower contentious issues. In addition, a

142. Joseph Sanders, Bendectin on Trial: A Study of Mass Tort Litigation 208 (1998). 
court-appointed expert is less likely to act as an advocate, and more likely to act in the ideal expert witness role-as an educator. Lastly, cross-examination will focus more on the scientific questions at issue, rather than arguments about competence and integrity.

Most judges have the authority to appoint experts on their own, but this authority is rarely invoked. ${ }^{143}$ This mechanism may be seldom used for several reasons: Judges do not want to interfere in what is viewed as the parties' prerogative, are not necessarily confident they would select the most appropriate expert, and are reluctant to do so out of concern that the selection of a courtappointed expert may be outcome determinative.

With regard to the first two concerns, judicial selection of an impartial expert will vastly increase the potential for the court to reach the "correct" and just decision in a case, even if the expert is not the absolutely best that could have been found. As discussed, party selection often leads to two polarized partial views, without sufficient regard to the actual state of scientific knowledge.

Finding an appropriate court-appointed expert is a challenge, but judges have several means at their disposal. First, they can require the parties to submit lists of appropriate experts and look for matches. Often biotechnology litigation may involve such particular issues that it may not take many recommendations before both parties suggest the same name. This method has been used with success in the past. ${ }^{144}$ Second, the court could ask the experts selected by each side to recommend additional experts. Often there will be mutually respected scientists in the field. Third, the court could contact scientists in related fields to ask for recommendations. Similarly, the court could contact legal academics in the relevant area, who often will be able to recommend well-respected scientists in the field.

As to the final concern, court-appointment of an expert need not be outcome determinative. The parties may be allowed to introduce their own experts as well. Should the court-appointed expert err, the court will have an opportunity to hear corrective testimony. Court appointment of experts still leaves substantial

143. See, e.g., FED. R. Evid. 706 (allowing for the appointment of expert witnesses on motion of the court). In other jurisdictions, courts have the inherent authority to appoint expert witnesses on their own. See, e.g., CAL. Evid. CODE $\S 730$ (West 2005); Kesseler v. Kesseler, 180 N.E.2d 402, 407 (N.Y. 1962).

144. See, e.g., Genentech, Inc. v. Boehringer Manheim GmbH, 989 F. Supp. 359 (D. Mass. 1997). 
control in the hands of the decision-maker, whether judge or jury. In rare cases where the court-appointed expert's testimony is outcome determinative, the science will have dictated such a result. This system thus achieves a balanced consideration of science, as opposed to a system that pushes a disregard for science.

When many biotechnology issues are investigated, a surprising degree of scientific consensus emerges. Use of court-appointed experts allows this consensus to be considered by the court and greatly increases the chances for a decision that properly accords with scientific understanding. 